\title{
Subacute cutaneous lupus erythematosus-like eruption from Tegafur
}

\author{
Michiaki Ueda, Jinro Komura, * Toshiaki Higashida, \\ Shozo Futamura, and Yasuo Asada \\ Department of Dermatology, Kansai Medical University, \\ Moriguchi, Osaka 570, Japan \\ *Department of Dermatology, Kitano Hospital, \\ Osaka, Japan
}

(Receivcd for publication September 27, 1988)

Key Words : Lupus erythematosus-like eruption, Tegafur.

\begin{abstract}
Summary
A female patient who developed subacute cutaneous lupus erythematosus-like eruption after taking Tegafur is reported. The patient had a history of LE cell phenomenon and antinuclear antibody, and anti RNP and anti ss-DNA antibodies were positive at the time of skin reaction.
\end{abstract}

\section{Introduction}

Tegafur is one of 5 -fluorouracil prodrugs that was synthesized in the Soviet Union and is used against adenocarcinomas with rather mild myelotoxicity ${ }^{\mathbf{1}}$. We experienced a patient who had a history of positive LE cell phenomenon and antinuclear antibody, underwent hysterectomy, received Tegafur and developed skin eruptions.

\section{Case Report}

A 60-year-old woman with erythematous skin lesions on the face, palms and soles was first seen on February 5, 1985. According to the patient, ten years earlier she was pointed out to have hypertension, positive LE cell phenomenon and positive anti DNA antibody $(160 \times)$. She had received no treatment, and skin lesions were not noticed. Her family history was not contributory. In September 1984, she underwent total hysterectomy because of uterus cancer. After the operation, 4500 rad cobalt was irradiated, and on December 4 she started to take Tegafur 600mg per day. About one month later she noticed skin lesions on the face, palms and soles. Also she notices mild tenderness and pain in the ankle. On the first examination, she was afebril and had no remarkable complaints other than skin. There were well defined, edematous, dark red patches on the forehead, on the dorsa of nose and between the nose and 
upper lip (Fig. 1), papuloerythematous lesions on the cheeks, erythema multiformelike lesions on the palms and edematous erythemas on the soles. Nail changes and lesions in the oral cavity were not seen.

Laboratory studies. Complete blood cell count, total protein, urinalysis, serum compliment levels, immunoglobulins, chest $\mathrm{X}$-ray and EKG were within normal limits. Test for rheumatoid factor was positive. The antinuclear antibody test was positive to a titer of $1: 320$ with a speckled pattern. The anti RNP antibody titer was positive up to $1: 10240$, while that of anti Sm was less than 40. SS-A, SS-B and Scl 70 antibodies were negative. DNA test was positive at titer of $1: 640$, but only anti ss-DNA IgG and IgM antibodies were positive at $100 \mathrm{u} / \mathrm{ml}$ or greater and $30 \mathrm{u} / \mathrm{ml}$, respectively. Anti ds-DNA IgG and IgM antibodies were negative. Anti histone antibody was not examined.

Histology (Fig. 2). Biopsy specimen was taken from the forehead. The epidermis was atrophic with marked basal cell liquefaction degeneration. Many colloid bodies were noticed. Lymphocyte was not infiltrating into the epidermis. In the dermis round cell infiltration was noticed around blood vessels and hair follicles.

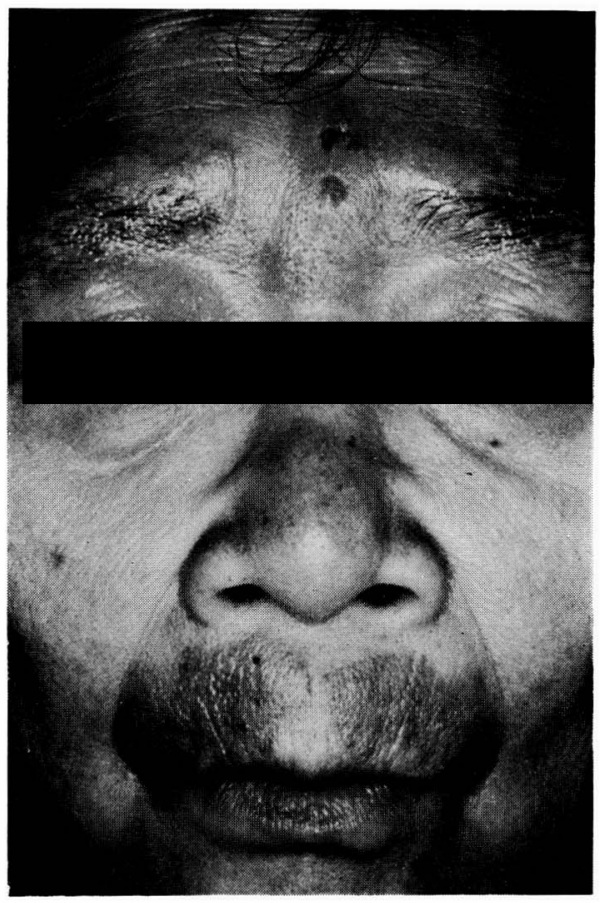

Fig. 1 Well defined, dark red patches on the forehead, on the dorsa of nose and between the nose and upper lip.

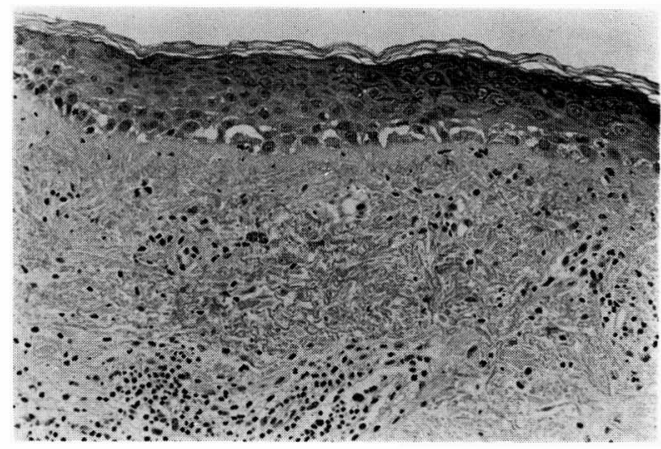

Fig. 2 The epidermis is atrophic with marked basal cell liquefaction degeneraton and colloid bodies. In the dermis round cell infiltration is noticed.

Course. Patient was hospitalized and predonisolone $600 \mathrm{mg}$ per day was prescribed reducing gradually. Tegafur was discontinued, and skin lesions disappeared in about two weeks. However, Tegafur was restarted on May 14 at $600 \mathrm{mg}$ per day, and the skin lesions reappeared as before on June 9 on the face, palm and soles. Patient was again hospitalized and treated with predonisolone. In November, patient received Tegafur 600mg per day to see whether the 
skin lesions would be provoked. 17 days later she developed arthralgia of the left ankle and tenderness in the soles causing difficulty in walking, and she was again hospitalized. No skin lesions were noticed at that time.

\section{Discussion}

Adverse cutaneous reaction to Tegafur has been reported mainly in the Japanese literature ${ }^{2)}$. It includes erythema, bulla, hyperkeratosis, pigmentation, nail changes, erosio in the oral cavity and genitalia, and photosensitivity. More recently, discoid lupus lupus erythematosuslike lesions have been noted ${ }^{3)}$. In DLE-like lesions, besides histology with atrophy of the epidermis and liguefaction degeneration of the basal layer, patients showed leukopenia, and positive antinuclear and DNA antibodies. In the present patient, the clinical feature of the face was that of papulosquamous pattern of subacute cutaneous lupus erythematosus, and the development of skin lesions was closely related to the intake of Tegafur. Compared with spontaneous SLE, features of drug-induced LE include milder symptoms which improve on cessation of drugs, presence of arthralgia and myalgias, positive antihistone antibody and negative DNA antibody, rarely positive lupus band test, and rare kidney and central nervous system involvement ${ }^{4,5)}$.

\section{References}

1) Sadée, W. and El Sayed, Y.M. : Mechanism of metabolic activation of Tegafur ; in Kimura et al (eds) : Fluoropvrimidines in cancer therapy. Fluoropyrimidines Symp., Nagoya 1983. Amsterdam, Excerpta Medica, 1984, pp 3〜11.

2) Tsuru, N., Niimura, M. and Ishibashi, Y. : Ftrafur dermatitis (in Japanese). Rinsyo derma., 19, 1157 1166, 1977.

3 ) Arase, S., Nakanishi, H., Nagai, T. and Shigemi, F. : Ftrafur induced lupus-wide spread DLE type (in Japanese). Rinsyo derma., 29, 951 957, 1987.

4 ) Kale, S. A. : Drug-induced systemic lupus erythematosus. Differentiating it from the real thing. Postgraduate Med., 77, 231 235, 238 239, 242, 1985.

5) Pavlidakey, G. P., Hashimoto, K., Heller, G. L., and Daneshvar, S. : Chlorpromazine-induced lupuslike disease : Case report and review of the literature. J. Am. Acad. Dermatol., 13, 109 115, 1985. 